\title{
Czym jest humanistyka cyfrowa? Pole semantyczne pojęcia (zarys)
}

\author{
Maria Przastek-Samokowa \\ Katedra Informatologii \\ Wydziat Dziennikarstwa, Informacji i Bibliologii \\ Uniwersytet Warszawski
}

\begin{abstract}
Abstrakt
Cel/Teza: Celem artykułu jest próba przedstawienia polskiego rozumienia pojęcia 'humanistyka cyfrowa' i stworzenie jego pola semantycznego.

Koncepcja/Metody badań: Stosując podejście językoznawcze, przeprowadzono językową i merytoryczną analizę wybranego materiału - niejednorodnego gatunkowo - zawierającego definicje i charakterystyki humanistyki cyfrowej.

Wyniki i wnioski: W wyniku analizy z tekstów wyabstrahowano znaczące swobodne słowa kluczowe (najistotniejsze elementy opisów/definicji HC) wraz z kontekstami ich użycia. Pozwoliło to na wyodrębnienie kategorii znaczeniowych (składników semantycznych nadrzędnego wyrażenia humanistyka cyfrowa). Zaproponowano dziewięć wyraźnych kategorii znaczeniowych pola semantycznego pojęcia 'humanistyka cyfrowa': 1) orientacja badawcza; 2) dziedzina/dyscyplina badawcza; 3) narzędzia; 4) projekty; 5) placówki i konsorcja; 6) formy komunikacji; 7) humanista cyfrowy; 8) kompetencje i umiejętności; 9) kierunek studiów.

Oryginalność/Wartość poznawcza: Artykuł - w podziale na aspekty, stające się kategoriami znaczeniowymi - ukazuje sposoby przedstawiania złożonego pojęcia 'humanistyka cyfrowa' oraz konstrukcję jego pola semantycznego. Uzyskane wyniki mogą stanowić punkt odniesienia dla dalszych badań dot. interpretacji pojęcia 'humanistyka cyfrowa' oraz dot. rozwoju samej humanistyki cyfrowej.
\end{abstract}

\section{Słowa kluczowe}

Deskrypcja. Humanistyka cyfrowa. Kategoria znaczeniowa. Pole semantyczne.

Otrzymany: 6 sierpnia 2016. Zrecenzowany: 2 stycznia 2017. Poprawiony: 6 stycznia 2017.

Zaakceptowany: 23 stycznia 2016.

\section{Wstęp}

Pojęcie 'humanistyka cyfrowa' (ang. digital humanities) jest w ostatnich latach tyleż często używane, a nawet modne, co niejednoznaczne. Badacze zarówno w Polsce, jak i za granicą zazwyczaj bardzo szeroko określają jego zakres i mimo upływu lat (w świecie co najmniej od lat 80. XX w. - od czasów „humanities computing”, w Polsce zaś od roku 2012, czyli od lubelskiej konferencji Cyfrowy zwrot w humanistyce) nadal dyskutują o kwestii granic i definicji humanistyki cyfrowej.

Niniejsze opracowanie jest próbą przedstawienia polskiego obrazu pojęcia 'humanistyka cyfrowa' i stworzenia jego pola semantycznego. 
Dla jego potrzeb przyjęto ogólną definicję pola semantycznego autorstwa Ryszarda Tokarskiego mówiącą, iż jest

to uporządkowana grupa wyrazów powiązanych przynależnością do wspólnej kategorii znaczeniowej (Tokarski 2001, 362).

Tokarski zalicza pole semantyczne do podklasy pól paradygmatycznych, pisząc:

Zasadą konstrukcji tej odmiany pól jest podobieństwo znaczeniowe elementów składowych, przy całkowitej dowolności ich strony formalnej (Tokarski 2013, 257).

Badanie pola semantycznego wymaga przeanalizowania tekstów różnego typu i rodzaju. Autorami wszystkich są osoby związane ze środowiskiem akademickim. Zebrany materiał jest więc niejednorodny i pochodzi z: artykułów naukowych, artykułów popularnonaukowych, zaproszeń na konferencje lub na wykłady specjalne, stron internetowych, wpisów na blogach z lat 2012-2016. Został pozyskany w wyniku najprostszego wyszukiwania internetowego i wstępnej selekcji. Wyabstrahowane z niego znaczące swobodne słowa kluczowe i wybrane konteksty, w których te słowa występują, pozwoliły na wyodrębnienie aspektów (składników semantycznych nadrzędnego wyrażenia humanistyka cyfrowa). Stały się one nazwami kategorii znaczeniowych tworzonego pola semantycznego pojęcia 'humanistyka cyfrowa"'.

\section{Czym jest humanistyka cyfrowa - orientacja badawcza}

W świetle przeanalizowanego materiału należy stwierdzić, że humanistyka cyfrowa jest uważana przede wszystkim za nurt, np.:

Humanistyka cyfrowa jest obecnie najdynamiczniej rozwijającym się nurtem badań naukowych ${ }^{1}$ (UMCS2)

- jeśli nurt może się rozwijać..., a nie np. przybierać na sile... (dopisek: MP-S):

Humanistyka cyfrowa wpłynie do głównego nurtu i z czasem nim się stanie (JK1).

Bywa, że nurt jest przeciwstawiany rewolucji/zmianie rewolucyjnej:

Humanistyka cyfrowa to nie kolejny (jeden z wielu) nurt we współczesnej praktyce badawczej, lecz rewolucyjna zmiana (AR).

Rewolucja cyfrowa/rewolucyjna zmiana, coś, co zrewolucjonizuje warsztat pracy współczesnego humanisty cieszy się nieco mniejszą frekwencją, np.:

Rewolucja cyfrowa w humanistyce to nie tylko ulepszenie maszyn do pisania i zastąpienie listów e-mailami (DELAB);

Humanistyka cyfrowa to [...] rewolucyjna zmiana, która przeobrazi czy już przeobraża krajobraz XXI-wiecznej nauki, a która jest konsekwencją tzw. digital turn (AR);

\footnotetext{
${ }^{1}$ Pisownia i interpunkcja wszystkich przykładów oryginalna.
} 
Humanistyka cyfrowa rewolucjonizuje warsztat pracy współczesnego humanisty, jego metodologię, strategie interpretacyjne, środki komunikacji i sposoby prowadzenia badań oraz prezentacji ich wyników (UMCS2, DELAB2).

Humanistyka cyfrowa bywa określana mianem dyscypliny lub dziedziny, np.:

niewielka dyscyplina, która co rusz żądli humanistykę głównego nurtu

i

Będąc dziedziną na skrzyżowaniu badań naukowych, informatyki i designu, humanistyka cyfrowa przejęła pałeczkę po humanistyce komputerowej (humanities computing) (JK1);

gwałtownie rozwijająca się dziedzina wiedzy (LSHC).

Warto też odnotować fakt nazwania jej naukq eksperymentalną:

Humanistyka cyfrowa jako nauka eksperymentalna (DELAB2).

HC jako nowe zjawisko/zjawisko, nowy ruch albo nowy model charakteryzuje się średnim użyciem. Występuje na przykład w następujących kontekstach:

Humanistyka cyfrowa jest nowym zjawiskiem we współczesnej praktyce badawczej (DELAB2);

Drugim nowym zjawiskiem w nauce jest rozwój humanistyki cyfrowej (HC) (MSt);

Jesteśmy świadkami narodzin nowego ruchu, który swym zasięgiem obejmuje nie tylko problemy badawcze i metodologiczne, lecz również organizacyjne, instytucjonalne, wydawnicze, a nawet aksjologiczne (AR);

Ruch humanistyki cyfrowej preferuje (JK4);

Konferencja ma promować nowy model humanistyki - humanistykę cyfrową (UMCS1).

Ponadto interesujące nas pojęcie nazywane jest: (nowym) polem (JK1);

To pole badań na skrzyżowaniu nauk humanistycznych, ale też informatyki oraz kognitywistyki (KN); nową ścieżką:

Cyfrowa Humanistyka (Digital Humanities) jest stosunkowo nową ścieżką, którą może podążyć nauka i przez tego samego autora obszarem:

Obszarem, który obejmuje filozofię, antropologię, socjologię nowych technologii, jak i stosowanie konkretnych narzędzi informatycznych w procesie badawczym, są Digital Humanities (ŁM);

nowa optyka (UMCS3);

metaforycznie odtrutka lub powiewem świeżości:

Humanistyka cyfrowa (i szerzej, nowy świat cyfrowy, z jego ekspansją sektorów kreatywnych) okazała się świetną odtrutką na rytualne lamenty humanistów z powodu rzekomego kryzysu dziedziny, domniemanego upadku jej prestiżu i gorszych perspektyw zatrudnienia dla absolwentów (JK1); 
Chociaż nauki humanistyczne od zawsze wydawały się jako najbardziej konserwatywne, to cyfrowy humanizm jest zaprzeczeniem i powiewem świeżości (KN);

koncepcja:

Koncepcja ta (HC - dop. MP-S) zrodziła się z idei połączenia refleksji humanistycznej z nowymi narzędziami cyfrowymi (UMCS2);

narzędziem:

Humanistyka cyfrowa jako narzędzie tradycyjnej humanistyki, czy samodzielna dyscyplina? (KUL1);

humanistyka cyfrowa może być dobrym narzędziem badań naukowych (GF)

i zwrotem cyfrowym:

Wyrażenie humanistyka cyfrowa traktuję jako metonimię oznaczającą zwrot cyfrowy (ES);

naktadka interdyscyplinarna:

Na razie to jest rodzaj interdyscyplinarnej nakładki, zainstalowanej na styku (mówiąc archaicznie) nauk humanistycznych, ścisłych i społecznych (JW).

\section{Czym jest humanistyka cyfrowa - dziedzina/dyscyplina badawcza}

W wielu analizowanych definicjach/charakterystykach humanistyki cyfrowej najczęściej wymienia się ogólnie humanistykę lub nauki humanistyczne, nauki społeczne, nauki ściste/ nauki »twarde«, kulturę, sztuke, jak i poszczególne dyscypliny badawcze, takie jak: literatura, informatyka, kognitywistyka, dziedzictwo kulturowe, kultura cyfrowa, statystyka, archiwistyka. Użycia ilustrują np. następujące konteksty:

Humanistyka cyfrowa polega na wykorzystaniu cyfrowych technologii i narzędzi w badaniach i edukacji w zakresie nauk humanistycznych i o sztuce (LSHC);

To pole badań na skrzyżowaniu nauk humanistycznych, ale też informatyki oraz kognitywistyki $(\mathrm{KN})$;

tworzenie nowych narzędzi dla humanistyki zajmującej się dziedzictwem kultury; zastosowania narzędzi cyfrowych do badania dawnej kultury oraz do badania samej kultury cyfrowej (JK1);

Humanistyka cyfrowa jest nie tylko z natury „międzydyscyplinowa” (łączy prace badaczy kultury, statystyków, informatyków, archiwistów, dokumentalistów), lecz także bardziej otwarta na inne dyscypliny z dziedziny humanistyki, nauk społecznych oraz „nauk twardych” (JK4);

Na razie to jest rodzaj interdyscyplinarnej nakładki, zainstalowanej na styku (mówiąc archaicznie) nauk humanistycznych, ścisłych i społecznych (JW);

Humanistyka cyfrowa polega na wykorzystaniu cyfrowych technologii i narzędzi w badaniach i edukacji w zakresie nauk humanistycznych i o sztuce (DARIAH1). 


\section{Czym jest humanistyka cyfrowa - narzędzia}

Narzędzia to nieodłączny element humanistyki cyfrowej. W analizowanych tekstach o narzędziach mówi się na dwa sposoby:

(1) ogólnie, używając np. określenia narzędzie cyfrowe/cyfrowe narzędzie:

Łączy zasoby cyfrowe i metody tradycyjnych dyscyplin humanistycznych z narzędziami cyfrowymi (JK1);

Dzięki tej dziedzinie podejmowane są tradycyjne problemy danej dyscypliny przy wykorzystaniu cyfrowych narzędzi. (NwP);

Koncepcja ta (HC - przyp. MP-S) zrodziła się z idei połączenia refleksji humanistycznej z nowymi narzędziami cyfrowymi (komputer, Internet, GPS i inne) (AR).

Rzadziej używa się innych wyrażeń o charakterze ogólnym, jak np.: narzędzia informatyczne, narzędzia teleinformatyczne/teleinformatyki, cyfrowe technologie i narzędzia. Przykładowe użycia:

Obszarem, który obejmuje filozofię, antropologię, socjologię nowych technologii, jak i stosowanie konkretnych narzędzi informatycznych w procesie badawczym, są Digital Humanities. (ŁM);

Humanistyka cyfrowa łączy dorobek tradycyjnej humanistyki z narzędziami teleinformatyki (GF);

Humanistyka cyfrowa polega na wykorzystaniu cyfrowych technologii i narzędzi w badaniach i edukacji (NwP);

(2) konkretnie, wymieniając nazwy narzędzi, np.:

Ważne zadania to: tworzenie cyfrowych narzędzi badawczych, za pomocą których można prowadzić badania na materiale cyfrowym (np. w AntiCone, T-Pen, TAPoR, image plot) (JK4);

Do dyspozycji cyberhumanisty pozostają takie narzędzia jak data mining bądź web mining (KN),

lub określając ich przeznaczenie:

zastosowanie narzędzi cyfrowych do badania dawnej kultury (np. projekt zbiorowy Mapping of the Republic of Letters) oraz do badania samej kultury cyfrowej (np. Wizualizacja danych jako metoda badania seriali TV, czy Badanie blogów: narzędzia humanistyki cyfrowej w analizie dyskursu elektronicznego);

Błędem byłoby także definiowanie HC wyłącznie przez narzędzia techniczne (wizualizacja danych, wzbogacona wizualność, narzędzia automatycznej analizy tekstów, wyszukiwanie informacji, wydobywanie danych, statystyka, analiza komputerowa, mapowanie więzi itd.) (JK1).

Niestety, czasem się zdarza, że kontekst nie pozwala odróżnić, co jest narzędziem, a co procesem. Np.:

Jedno z nich to tworzenie nowych narzędzi dla humanistyki zajmującej się dziedzictwem kultury. Np. konwersja katalogów niecyfrowych na cyfrowe, narzędzia do odczytania starych druków i rękopisów, narzędzia do sporządzania adnotacji, przypisów i komentarzy, cyfryzacja dawnych edycji źródeł (JK1) [podkr. - MP-S].

Ponadto w zebranym materiale występują również wyrażenia: (nowoczesna) technologia/-e, technologie cyfrowe, metody oraz konkretnie metody statystyczne/ilościowe, które 
w niniejszym opracowaniu postanowiono włączyć do kategorii „Narzędzia”. Ilustracją użyć są następujące przykłady:

Stawianie są również nowe pytania badawcze, które umożliwia technologia (NwP);

Naukowcy-humaniści, przedstawiciele takich dyscyplin jak historia, literaturoznawstwo, a nawet języki klasyczne, zaczynają wykorzystywać nowoczesną technologię (zwłaszcza różne typy rozwiązań IT) w prowadzeniu badań (LSCH);

Technologie cyfrowe zmieniły mechanizmy ewolucji humanistyki (JK1);

Nowoczesne technologie w badaniach humanistycznych (KB);

Technologie cyfrowe mogą występować w kontekście humanistyki w przynajmniej podwójnej roli: jako temat badań i jako ich narzędzie - i to w tym drugim znaczeniu najczęściej używa się terminu "cyfrowa humanistyka" (MSm);

Humanistyka cyfrowa - gwałtownie rozwijająca się dziedzina wiedzy - eksploruje nowe możliwości, jakie niesie zastosowanie metod statystycznych (ilościowych) w badaniach literatury (LSCH);

wykorzystywane są zarówno do usprawnienia tradycyjnych badań, przetwarzania, wizualizowania, prezentowania i popularyzowania wyników badań naukowych, ale również kreują swoje własne metody i perspektywy badawcze (UMCS2);

Na jej gruncie wypracowano szereg nowatorskich narzędzi i metod pozwalających na eksplorację współczesnej cyfrowej kultury i zdigitalizowanego dziedzictwa kulturowego ludzkości (UMCS2).

\section{Czym jest humanistyka cyfrowa - projekty}

Projekty cyfrowe traktowane są jako czynniki nowego paradygmatu badań humanistycznych. W analizowanym materiale często wymieniane są z nazwy, np.:

dofinansowanie nowych typów w pełni już cyfrowych, multimedialnych i interaktywnych projektów (np. Rome Reborn, British History Timeline, Scholasticon, Lublin 2.0) (JK4);

projekty (np. „Cyfrowe Muzeum Narodowe”, „Polska Bibliografia Literacka”, „Teatr Wielki - budowla i jej otoczenie" Darii Rzepieli) (JW);

Uczestnicy konferencji opowiadali o projektach humanistycznych rozwijanych na Uniwersytecie Warszawskim i wykorzystujących nowoczesne technologie. Instytut Informacji Naukowej i Studiów Bibliologicznych prowadzi dwie biblioteki cyfrowe: Bibliologiczną Bibliotekę Cyfrową oraz Polonijną Bibliotekę Cyfrową. Instytut Historyczny zdigitalizował kolekcję starych druków zawierającą 1003 dzieł z XVI-XVII wieku, w tym historyczne kolekcje dawnej Biblioteki Senatu Gdańskiego oraz Zamku w Malborku, a także cenne druki kartograficzne: atlasy, mapy i plany [...] Nowym projektem Wydziału Historycznego jest otwarte repozytorium nauk humanistycznych Lectorium (HCUW).

Część projektów została także pokrótce omówiona, np.:

Academica jest wzorowym przykładem „digital humanities”, jakkolwiek jest wiele innych, bardziej zaawansowanych działań, ściśle związanych z samą techniką prowadzenia badań w sieci. Warunkiem „digital humanities" jest przede wszystkim dostęp do źródeł i publikacji cyfrowych, a to właśnie 
zapewnia Academica. Mam nadzieję, że wkrótce będzie to największe repozytorium cyfrowe w Polsce, prawdopodobnie także jedno z największych w Europie (WB);

Szczególną uwagę warto zwrócić na projekt Atlas źródeł i materiałów do dziejów dawnej Polski. Głównym celem projektu jest zbudowanie jednolitego systemu do gromadzenia, analizy i udostępniania informacji oraz źródeł do badań z zakresu geografii historycznej ziem polskich w granicach sprzed 1772 roku. Platforma informatyczna będzie prezentować wyniki badań geograficzno-historycznych prowadzonych w różnych ośrodkach badawczych w Polsce i za granicą. (JK2);

Największym i najpotężniejszym projektem w ramach cyfrowej humanistyki jest Google Books, którego bazę tworzy ok. 30 milionów zdigitalizowanych książek (12\% wszystkich książek stworzonych dotychczas przez człowieka (MWT).

Uzupełnienie materiałowe tej kategorii mogą stanowić dwie listy polskich projektów: Humanistyczne projekty cyfrowe w Polsce oraz e-humanistyka w Polsce ${ }^{2}$.

\section{Czym jest humanistyka cyfrowa - placówki i konsorcja}

\section{Placówki i konsorcja wymieniane są z nazwy:}

Uniwersytet Warszawski, w ramach konsorcjum DARIAH-PL, zajmującego się rozwojem humanistyki cyfrowej w Polsce, powołał właśnie Laboratorium Cyfrowe Humanistyki (NG);

Uniwersytet Warszawski i Google tworzą Digital Economy Lab (DELab) - interdyscyplinarny ośrodek badań nad rozwojem technologii informacyjnych i komunikacyjnych (MNiSW);

Poza już tu wspomnianym Wydziałem Humanistycznym AGH, od dłuższego czasu funkcjonuje Centrum Humanistyki Cyfrowej IBL PAN oraz Zespół Inżynierii Lingwistycznej PAN, jak też polska odnoga europejskiej struktury poznawczej CLARIN PL. [...] Istnieją i specjalistycznie kształcą: Katedra Lingwistyki Komputerowej UJ, Zakład Lingwistyki Komputerowej USz, Zakład Lingwistyki Informacyjnej i Sztucznej Inteligencji UAM oraz Instytut Kulturoznawstwa UMCS (JW);

Platforma nie powstanie bez współpracy historyków („przymiotnikowych” i „bezprzymiotnikowych”), geografów historycznych, informatyków, bibliometrów, a także statystyków i fizyków (ci ostatni stanowią największą grupę badaczy sieci). Konsorcjum DARIAH byłoby jego najlepszym adresatem. To heroiczne zadanie dla DARIAH, ale może sensowne, jeśli konsorcjum nie ma się stać jedynie pojemnikiem na wiele różnych, niepowiązanych ze sobą, małych projektów (JK3);

Polska weszła do DARIAH-ERIC (DARIAH1);

18 sierpnia 2014 r. podpisano umowę o ustanowieniu konsorcjum DARIAH-PL, którego podstawowym celem jest wprowadzenie Polski do europejskiej sieci DARIAH - ERIC (Digital Research Infrastructure for the Arts and Humanities) oraz pogłębienie i rozbudowanie współpracy ośrodków prowadzących projekty w zakresie humanistyki cyfrowej i dysponujących infrastrukturą w tym zakresie. Konsorcjum stworzyło 13 instytucji, a jego liderem został Uniwersytet Warszawski (KB).

\footnotetext{
${ }^{2}$ Pełne adresy w wykazie źródeł.
} 


\section{Czym jest humanistyka cyfrowa - formy komunikacji}

Na kategorię „Formy komunikacji” w humanistyce cyfrowej składają się występujące w analizowanym materiale formy tradycyjne: konferencje, wykłady, warsztaty i formy nietradycyjne: THATCampy, „niekonferencje”, blogi. Ich różnorodność pokazują teksty przytaczane w niniejszym artykule i wykaz źródeł.

\section{Czym jest humanistyka cyfrowa - humanista cyfrowy}

Analiza zebranego materiału pozwala na wyodrębnienie jeszcze jednego „elementu” humanistyki cyfrowej, czyli cyfrowego humanisty/humanisty cyfrowego. Świadczą o tym następujące przykłady użyć:

Cyfrowy humanizm daje też szansę humanistom na zerwanie z wizerunkiem osób pozbawionych
praktycznych umiejętności, wartościowych na rynku pracy. Wręcz przeciwnie, cyfrowy humanista to
człowiek renesansu XXI wieku. Nie tylko zna się na sztuce, literaturze i teorii, ale też technologii (KN);

Humanista otrzymuje dziś niespotykane dotąd narzędzia, dzięki którym poszerza pole eksploracji. Humanistą cyfrowym jest nie tylko badacz używający cyfrowych narzędzi, to także tradycyjny humanista, któremu po prostu zmienił się przedmiot badań. [...] Rolą humanisty jest teraz szukanie heurystyk i metafor określających współczesną rzeczywistość (GF);

Absolwent kierunku [humanistyka cyfrowa - dop. MP-S] to - w założeniu - humanista przygotowany do funkcjonowania w świecie cyfrowym, który poza umiejętnościami technicznymi świetnie rozpoznaje psychologiczne potrzeby komunikacji społecznej, potrafi pracować w zespole, zna prawo internetu i mediów. Nowy humanista ma sprawnie operować narzędziami wiedzy teoretycznej oraz praktycznej (cyfrowej) (KUL2).

\section{Czym jest humanistyka cyfrowa - kompetencje i umiejętności}

Wśród kompetencji i umiejętności potrzebnych do tworzenia humanistyki cyfrowej i/lub uczestniczenia w humanistyce cyfrowej - w analizowanym materiale - wymieniane są np.: umiejętność pracy zespołowej, umiejętność znajdowania wspólnego języka ze specjalistami z różnych dyscyplin, umiejętność współdziałania, znajomość narzędzi i zmian w nich zachodzących, umiejętność interpretacji danych cyfrowych. Przykłady użyć:

Kompetencje grupy przekraczają kompetencje możliwe (zazwyczaj) do osiągnięcia przez jednostki. Badacze wzajemnie podsycają swoją ciekawość, organizuje się burze mózgów, wspólnie szuka najlepszych rozwiązań, lider narzuca wizję, inspiruje i doradza. Wzajemna weryfikacja danych i ustaleń jest skuteczniejsza niż kiedy przeprowadza ją ten, kto sam prowadzi badania (JK1);

Jakie umiejętności są potrzebne, by tworzyć humanistykę cyfrową? Przy projektach pracują ludzie różnych specjalności, informatycy, graficy, graficy 3D, programiści, historycy, historycy sztuki, archeolodzy, socjolodzy. Podstawową umiejętnością jest więc znalezienie wspólnego języka. Humaniści nie muszą znać języków programowania, lecz powinni rozumieć uwarunkowania pracy informatyków i na odwrót. Już na wczesnym etapie studiów adepci informatyki i humanistyki mogliby korzystać ze wspólnych zajęć, uczestniczyć we wspólnych projektach. Ważna jest też po prostu umiejętność 
współdziałania, zdolność budowania mostów między środowiskami, przełamywania podziału na dwie kultury;

Do tworzenia humanistyki cyfrowej konieczne jest ciągłe poszerzanie kompetencji, nadążanie za zmianą narzędzi, które dynamicznie się rozwijają. Niektórzy humaniści cyfrowi poprzestają bowiem na pewnym etapie, znalazłszy sobie własny ogródek, i nie posuwają się dalej. Z drugiej strony istnieje przecież niebezpieczeństwo intelektualnego wyjałowienia w pogoni za technologią i gadżetami, zagubienia sensu i celu badań (GF);

Na konferencji zwrócono uwagę, że do kompetencji humanisty powinna należeć umiejętność interpretacji danych cyfrowych. Powinno się choć na tyle rozumieć procesy cyfrowe, by wiedzieć, co się otrzymało i w jakim stopniu wyniki mogą być zależne od uwarunkowań związanych z kodem czy z użytą platformą. Wspominano, że warto się orientować, jakie narzędzia są dostępne i tworzyć ich zestawy do wykorzystania we własnej pracy (GF);

Humanistom cyfrowym przystoi myśleć o edukacji, zajmować się nieco przewidywaniem przyszłości, myśleć o zakresach kompetencji, które będą potrzebne do funkcjonowania w cyfrowej rzeczywistości (GF).

\section{Czym jest humanistyka cyfrowa - kierunek studiów}

W zgromadzonym materiale mowa jest również o tym, iż humanistykę cyfrową można studiować na KUL, UMCS i UKW w Bydgoszczy.

Z opisu kierunku na studiach II stopnia na KUL:

Kierunek odpowiada na potrzeby nowoczesnego rynku pracy, kształcąc zarówno w zakresie kompetencji humanistycznych jak i zaawansowanej znajomości programów cyfrowych, wykorzystywanych m.in. w pracy redaktora czy polonisty. Absolwent kierunku to - w założeniu - humanista przygotowany do funkcjonowania w świecie cyfrowym, który poza umiejętnościami technicznymi świetnie rozpoznaje psychologiczne potrzeby komunikacji społecznej, potrafi pracować w zespole, zna prawo internetu i mediów. Nowy humanista ma sprawnie operować narzędziami wiedzy teoretycznej oraz praktycznej (cyfrowej) (KUL2);

ponadto np.

Gdzie studiować humanistykę cyfrową w Polsce? Subiektywny przewodnik (RB).

\section{Podsumowanie}

Analiza zebranego materiału potwierdziła różnorodność ujęć w opisie humanistyki cyfrowej. Udało się jednak ustalić wspólne kategorie znaczeniowe, uporządkować w ich ramach wybrane z tekstów znaczące swobodne słowa kluczowe i na koniec pokusić się o próbę stworzenia zarysu pola semantycznego $\mathrm{HC}$.

W interpretacjach lub sposobach prezentacji problematyki, przedstawianych przez autorów analizowanych materiałów źródłowych, widać przekonanie o naukowym charakterze i jednocześnie potencjale humanistyki cyfrowej jako orientacji lub (sub)dyscypliny badawczej. To przekonanie opiera się najczęściej na faktycznych i spodziewanych efektach zastosowania narzędzi informatycznych do humanistycznego materiału badawczego. 
Skuteczność projektowania i stosowania takich narzędzi zależy jednak w znacznym stopniu od interdyscyplinarnej pracy zespołowej (co widać w powstawaniu nowych placówek czy realizowanych projektach), obejmującej zarówno łączenie różnych kompetencji członków zespołu, jak i wykorzystania kompetencji miękkich, ułatwiających taką formę pracy (jak i niekiedy decydujących o sukcesie).

Biorąc pod uwagę intuicyjność i deklaratywność części prezentowanych wyżej wypowiedzi, trzeba szczególnie podkreślić, że proponowane tu pole semantyczne jest z pewnością zaledwie szkicem (rekonesansem) - punktem wyjścia dla dalszych opracowań. Jego płynność i niejednoznaczność wynika z uchwycenia wczesnego etapu wprowadzania pojęcia HC do polskiego obszaru badawczego. Obecność i możliwe zmiany bądź stabilizacja interpretacji tegoż wymagają bezsprzecznie stałej obserwacji i dalszych badań.

\section{Bibliografia}

Tokarski, R. (2001). Słownictwo jako interpretacja świata. W: J. Bartmiński (red.). Wspótczesny język polski. Lublin: Wydaw. Uniwersytetu Marii Curie-Skłodowskiej.

Tokarski, R. (2013). Światy za słowami. Wykłady z semantyki leksykalnej. Lublin: Wydaw. Uniwersytetu Marii Curie-Skłodowskiej.

\section{Wykaz cytowanych źródeł}

AR - Radomski, A., Humanistyka cyfrowa w praktyce - analiza $i$ wizualizacja obrazów [online] [19.07.2016], https://depot.ceon.pl/xmlui/bitstream/handle/123456789/9727/humanistyka_cyfrowa.pdf?sequence $=3 \&$ is Allowed $=\mathrm{y}$

DARIAH1 - Polska weszła do DARIAH-ERIC - informacja w zakładce »Aktualności« [online] [19.07.2016], https://forumakademickie.pl/aktualnosci/2015/11/9/3133/polska-weszla-do-dariah-eric/

DELAB - Tekst reklamujący wykład prof. Wioletty Miśkiewicz [online] [1.05.2016], http://www. delab.uw.edu.pl/co-to-jest-humanistyka-cyfrowa/ = DELAB

DELAB2 - Informacja o odbytym wykładzie: Andrzej Radomski (UMCS): HUMANISTYKA CYFROWA - czyli rewolucja w praktyce badawczej [online] [19.07.2016], http://www.delab.uw.edu. $\mathrm{pl} /$ andrzej-radomski-humanistyka-cyfrowa-czyli-rewolucja-w-praktyce-badawczej/

e-humanistyka w Polsce [online] [01.05.2016], http://clarin-pl.eu/pl/e-humanistyka-w-polsce/

ES - Solska, E., Nowa Respublica Litteraria? Humanistyka cyfrowa jako metaorientacja współczesnych badań humanistycznych, Roczniki Kulturoznawcze 2016, T. 7, nr 1 [online] [19.07.2016], https:// tnkul.pl/files/userfiles/files/RKult2015nr1_099-118_Solska.pdf

GF - Filip, G., Cyfrowy wariant humanistyki [online] [20.07.2016], https://forumakademickie.pl/ $\mathrm{fa} / 2016 / 02 /$ cyfrowy-wariant-humanistyki/

HCUW - Humanistyka cyfrowa na UW - tekst ze strony UW z działu »Aktualności« [online] [20.07.2016], http://www.uw.edu.pl/humanistyka-cyfrowa-na-uw/

JK1 - Jan Kozłowski, Giez Sokratesa [online] [20.07.2016], https://forumakademickie.pl/fa/2012/12/ giez-sokratesa/

JK2 - Jan Kozłowski, DARIAH i nowe formy działań w nauce [online] [20.07.2016], https://forumakademickie.pl/fa/2014/05/dariah-i-nowe-formy-dzialan-w-nauce/ = JK2

JK3 - Kozłowski, J., Humanistyka oparta na danych czyli prawdziwy koniec Wilhelma Windelbanda. Projekt utopijny [online] [20.09.2016], https://www.forumakademickie.pl/fa/2015/12/humanistyka-oparta-na-danych $/=\mathrm{JK} 3$ 
JK4 - Kozłowski, J., Co z ta polskq humanistyka?? [online] [20.07.2016], https://forumakademickie. $\mathrm{pl} / \mathrm{fa} / 2016 / 02 /$ co-z-ta-polska-humanistyka/

JW - Wojciechowski, J., W stronę e-humanistyki [online] [20.07.2016], https://forumakademickie. $\mathrm{pl} / \mathrm{fa} / 2014 / 12 / \mathrm{w}$-strone-e-humanistyki/\# = JW

KB - Brylska, K. (opr.), Humanistyka cyfrowa, [online] [19.07.2016], https://forumakademickie.pl/ $\mathrm{fa} / 2015 / 10 /$ humanistyka-cyfrowa/ $=\mathrm{KB}$

KN - Nowakowski, K., Czym jest cyfrowy humanizm [online]. W: SocialNety [16.06.2016], http:// www.socialnety.pl/czym-jest-cyfrowy-humanizm/

KUL1 - Tekst zaproszenia na konferencję Humanistyka cyfrowa wobec humanistyki stowa [online] [01.05.2016], http://unikonferencje.pl/miniona/konf-uzasy9ujeh

KUL2 - Tekst oferty studiów magisterskich Humanistyka cyfrowa wiedza z widokiem na przyszłość [online] [20.07.2016], http://www.kul.pl/humanistyka-cyfrowa, = KUL

ŁM - Mirocha, Ł., CZiT na Chicago Colloquium on Digital Humanities and Computer Science. Czesść pierwsza - wykorzystanie nowych technologii w humanistyce - wpis na blogu Ł. Mirochy „Człowiek i Technologie” [online] [1.05.2016], http://czlowiekitechnologie.com/czit-na-chicagocolloquim-on-digital-humanties-and-computer-science-czesc-pierwsza-wykorzystanie-nowychtechnologii-w-humanistyce/

LSCH - Tekst zaproszenia na Letnią Szkołę Humanistyki Cyfrowej [online] [20.07.2016], https:// sites.google.com/site/letniaszkoladh/home

MM -Maryl, M., Co to jest humanistyka cyfrowa - odpowiedź na ankietę Czasu Kultury 2015, 2 [online] [1.05.2016], http://maryl.org/wp-content/uploads/2016/05/Maryl-2015-Co-to-humanistyka-cyfrowa.pdf

MNiSW - Milion dolarów od Google dla UW na badania nad rozwojem nowych technologii informacyjnych - tekst ze strony MNiSW [online] [20.07.2016], http://www.nauka.gov.pl/ aktualnosci-ministerstwo/milion-dolarow-od-google-dla-uw-na-badania-nad-rozwojem-nowychtechnologii-informacyjnych.html

MSm - Smoleń, M., Cyfrowe humanistyki. Respublika [online] [19.07.2016], http://publica.pl/teksty/ cyfrowe-humanistyki-45764.html

MSt - Starczewski, M., Otwarte modele komunikacji naukowej a humanistyka cyfrowa [online] [20.07.2016], http://repozytorium.ceon.pl/bitstream/handle/123456789/6016/Otwarte\%20modele\%20komunikacji\%20naukowej\%20a\%20humanistyka\%20cyfrowa.pdf?sequence=1\&isAllowed=y

MWT - Wieczorek-Tomaszewska M., Cyfrowa humanistyka jako wspótczesna metaforyczna Republika Listów [online] [19.07.2016], http://www.ktime.up.krakow.pl/symp2013/referaty_2013_10/ wieczorek.pdf

NG - Nowa era humanistów? W Polsce rozwija się humanistyka cyfrowa - informacja [online] [19.07.2016], http://www.national-geographic.pl/aktualnosci/nowa-era-humanistow-w-polscerozwija-sie-humanistyka-cyfrowa

NwP - Polska humanistyka cyfrowa bliżej struktur europejskich [online] [20.07.2016], http://naukawpolsce.pap.pl/aktualnosci/news,404022,polska-humanistyka-cyfrowa-blizej-struktur-europejskich. html

RB - Bomba, R., Gdzie studiować humanistykę cyfrowa w Polsce. Przewodnik subiektywny - wpis na blogu „Bomba.Blog” [online] [19.07.2016], http://rbomba.pl/archives/1789

UMCS1 - Tekst zaproszenia na konferencję Zwrot w humanistyce cyfrowej [online] [1.05.2016], http://humanistykacyfrowa.umcs.lublin.pl/konferencja/ = UMCS 1

UMCS2 - Tekst zaproszenia na konferencję: HUMANISTYKA CYFROWA - badanie tekstów, obrazów i dźwięku [online] [19.07.2016], http://2015.dariah.pl/pl/zaproszenie/

UMCS3 - Promocja książki Zwrot cyfrowy w humanistyce [online] [20.06.2016] http://lubimyczytac.

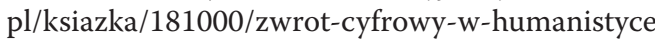


WB - Bolecki, W., Wypowiedź w tekście Poszerzenie wolnego dostępu [online] [20.07.2016], https://forumakademickie.pl/aktualnosci/2014/10/10/2166/cyfrowa-wypozyczalnia-publikacji-naukowychacademica $/=$ WB

Werla, M.; Maryl, M., Humanistyczne projekty cyfrowe w Polsce [online] [01.05.2016], http://lib.psnc. $\mathrm{pl} /$ dlibra/docmetadata?id $=655 \&$ from $=$ publication

\title{
Digital Humanities - a Draft of the Semantic Field of the Concept
}

\begin{abstract}
Purpose/Thesis: The aim of this paper is to present Polish interpretations of the concept of 'digital humanities' and its semantic field.

Approach/Methods: The linguistic and content analysis of selected heterogeneous material, including both definitions and characteristics of digital humanities.

Results and conclusions: The analysis of the resources resulted in the extraction of significant keywords (the most important elements of descriptions/definitions), together with their contexts. That enabled the author to distinguish semantic categories (semantic elements of the mother phrase 'digital humanities'). Nine discrete semantic categories of the semantic field of the concept of 'digital humanities' have been identified: 1) research orientation; 2) research domain/discipline; 3) tools; 4) projects; 5) units and consortia; 6) communication forms; 7) digital humanist; 8) competences and skills; 9) degree course.

Originality/Value: The paper, arranged according to the aspects finally turned into semantic categories, discusses presentation modes of the complex concept of 'digital humanities' and the structure of its semantic field. The results can be useful for further research concerning both the interpretation of the concept itself and the development of digital humanities.
\end{abstract}

\section{Keywords}

Description. Digital humanities. Semantic category. Semantic field.

Dr MARIA PRZASTEK-SAMOKOWA pracuje w Katedrze Informatologii na Wydziale Dziennikarstwa, Informacji i Bibliologii UW. Z wykształcenia językoznawca-slawista swoje zainteresowania badawcze koncentruje wokót zagadnień dot. użytkowników informacji, komunikacji językowej, e-slawistyki. Jest członkiem Komisji Bibliografii Lingwistycznej przy Międzynarodowym Komitecie Slawistów, a także członkiem międzynarodowego zespotu opracowujacego bibliograficzna bazę danych światowego językoznawstwa slawistycznego iSybislaw, dostępnego w Internecie (www.isybislaw.ispan.waw.pl).

\author{
Kontakt $z$ autorka: \\ m.przastek-samok@uw.edu.pl \\ Katedra Informatologii \\ Wydziat Dziennikarstwa, Informacji i Bibliologii \\ Uniwersytet Warszawski \\ Nowy Świat 69 \\ 00-927 Warszawa
}

